\title{
NOVUS ACTUS INTERVENIENS IN THE CONTEXT OF CRIMINAL LAW IN INDONESIA
}

\author{
Ahmad Sofian \\ Business Law Department, Faculty of Humanities, Bina Nusantara University \\ Jl. KemanggisanIlir III no. 45, Palmerah, Jakarta, 11480 \\ asofian@binus.edu
}

\begin{abstract}
The doctrine of novus actus interveniens used in causation to establish the liability of the principle offender for a prohibited result. The doctrine can be used in various legal fields in both civil and criminal law. The aim of this study was finding the kind of intervention that conducted by another actor, a victim or a medical worker, a non-human agent such as an animal or nature, could influenced the judge's decisions in determining the defendant in accordance with novus actus interveniens doctrine. The method used was the normative method. The normative method in the study of jurisprudence was a method used to study secondary data sources on some legal documents. These secondary data sources were composed of some legal materials, namely primary legal materials consisting of the KUHP (the Indonesia Penal Code) and court decisions that have permanent legal force. This study finds that the doctrine of novus actus interveniens unfortunately is not commonly used by judges, prosecutors, lawyers and legal experts in Indonesia even though it can be used to solve problems in finding material truth.
\end{abstract}

Keywords: novus actus interveniens, intervention, causality, criminal law

\section{INTRODUCTION}

If we talk about the doctrine of novus actus interveniens, it cannot be detached from the teachings of causality in law. The novus actus interveniens doctrine is one of the factors that determine the attribution of responsibility for the action that leads to the prohibited result e.g. environmental pollution, traffic accidents, damage arising from breach of contract or illegal acts, acts that cause harm and risk. In criminal law, causality is also needed in offenses which cause death, health problems for a person or group of people, injuries, fire, or damage. In economic law, causality is applied when assessing the losses arising from the cancellation of a contract or when someone fails to meet the requirements of a clause in that contract.

This doctrine is more widely used by prosecutors, lawyers, and judges in common law countries, but this does not mean that this doctrine cannot be used in civil law countries. Steps to determine novus actus interveniens are taken when a legal event has occurred in which there is an act or series of acts that are regarded as the cause and a result occurs. Then there is a third party that intervenes in the causal sequence, which causes other results or which worsens the appeared result.

Although this doctrine developed in countries that embrace the tradition of common law, in some cases it is incorporated in Indonesia, for example during the plea of an attorney, though academically it is not called novus actus interveniens. In the case of PT DEI, a company that disposed of hazardous liquid waste into uncultivated land in Cikarang Utara, the prosecutor charged the defendant with environmental pollution that caused damage to the environment and caused nausea, dizziness and dry throat for a portion of the residents in the region. In one of the pleas, the attorney 
said that the relationship between the defendant's dispose of waste, and the onset of nausea, vomiting, and dizziness in some people could not be proven. Only dozens of the residents experienced nausea, dizziness, and vomiting while most of them did not experience the symptoms mentioned in the prosecutor's accusation. It can be interpreted that, in his defense, the attorney was seeking a novus actus interveniens or intervention that resulted in part of the residents experiencing nausea, dizziness, and itchy throat. However, the event or action that intervened was not mentioned in the defense. Therefore, the Supreme Court decided to punish PT DEI, represented by its Director with a fine of Rp 650 million or a sentence of 6 months imprisonment in case the fine was not paid (Supreme Court Decision No. 862 K/Pid.Sus/2010: 92).

\section{METHODS}

The method employed in this study is the normative method. The normative method in the study of jurisprudence is a method used to study secondary data sources on some legal documents. These secondary data sources are composed of three legal materials, namely primary legal materials consisting of the KUHP (the Indonesia Penal Code) and court decisions that have permanent legal force. Court decisions that have permanent legal force consist of decisions related to substantive criminal offenses that cause the prohibited result. Secondary legal materials consist of various legal literature sources on the doctrine of causality and the doctrine of novus actus interveniens from the common law as well as the civil law family. Meanwhile tertiary legal materials, like the dictionary of the philosophy of law and the legal dictionary, are materials that explain secondary legal materials.

\section{RESULTS AND DISCUSSIONS}

Novus actus interveniens or nova causa interveniens is a Latin terminology that is defined as the intervention of an independent third party. The Black Law Dictionary translates novus actus interveniens (nova causa interveniens) as an intervening cause. It is defined as an event that comes between the initial event in a sequence and the result, thereby altering the natural course of events that might have connected a wrongful act to an injury (Gerner, 2004). Novus actus interveniens later developed into one of the doctrines in the teachings of causality that popularized by H.L.A. Hart and A.M. Honore in their book entitled Causation in Law, which was first published in 1959. Hart and Honore were both professor in jurisprudence at Oxford University (Hart \& Honore, 1959). Another British author, Williams said that the new intervening act or novus actus interveniens of a responsible actor, who has full knowledge of what he is doing, and is not subject to pressure, intimidation or mistake, will normally operate to relieve the defendant of liability for a further consequence. It makes the consequence too remote (Remmelink, 2014).

In the family of common law, novus actus can be translated as new actions or new causes, superseding, extraneous, intervening forces, intervening act, intervening agency, independent intervening cause that is described as beginning as deed or action that can break a series of actions that have a causal relationship. Therefore, novus actus stops the causal relationship or will shortly after stop it from moving or run it out of power so it cannot continue the causal chain. If there is no one breaks the chain, then the chain has the potential to continue, give a contribution, the move which will lead to certain consequences (J. Remmelink, 2014). An intervention happens between or in the midst of an event. If an intervention is strong enough, it can reduce the liability of the offender and the intervening party can replace his liability. But it should be noted that the intervening party is an independent party and not a party that is forced to participate or a party that took part in the act so it can replace such liability (Bryan A. Gerner, 2004). 
Hart \& Honore (1959) interpret novus actus interveniens as a superseding cause or intervening cause that can break the chain of causality so it can eliminate the liability or reduce the nature of liability of the main actor (principle offender). Thus, there is a third party that intervenes and breaks the chain of causality. If that third party intervention is carried out by another actor, it means that the intervention is done consciously, freely and without coercion. For example, A throws a cigarette butt into the bushes at the edge of the forest. Unbeknownst to A, B then pours gasoline into the bushes, which causes a forest fire. Is it A's deed that caused the forest fire when he did not intend to burn down the forest? Of course, A is not responsible for the forest fire; it is B's intervention that caused the forest fire (Hart \& Honore, 1959). In this case, B is not an instrument of A, and A did not tell or suggest B to pour gasoline on the cigarette butt to burn the forest, it is purely an act on the initiative of $\mathrm{B}$ himself. He was exploiting the situation and caused a fire without being an element of cooperation with A. It is a different case if A and B both intended to burn the forest, then they had the same intention to burn the forest, and that shared intention would result in the forest fire. Meanwhile, in the case described in this paragraph, A had no intention to burn the forest, while B intentionally poured gasoline onto the cigarette butt which caused the fire. Thus, an element of malicious intent (mens rea) can only be attributed to B and not to A. Therefore, moral considerations become important in determining whether there is an intervention of another actor that reduces or erases the liability of the first actor (Hart \& Honore, 1959).

Here is another example for comparison; A hits B, and as a result B loses his balance. While staggering B crashes into a window glass till it shatters. In this case, we can say that A caused B to lose his balance and break the window glass, and we cannot say that A broke the window glass. In short, it can be said that A's action gives attribution or contribution to the breaking of the window glass. In the latter case, $B$ had no intention to break the window, but he caused the window glass to break because of A's deed. Likewise, A had no intention to break the window glass. However, A is still responsible because he should have been able to predict the result of his action. Although the levels of responsibility for the breaking of the window glass cannot be blamed $100 \%$ to A. Meanwhile B's deed of breaking the window glass is done in addition to him having no intention to break it. The breaking of the window glass is an act that happened involuntarily and not a voluntary act (Hart \& Honore, 1959).

The following concept also gives an understanding similar to the concept proposed by Hart \& Honore (1959). However, this concept emphasizes more on the emergence of other impacts or consequences that cannot be controlled by a previous offender. The previous offender has committed an act or omission containing intentional or negligent elements. In this concept, novus actus interveniens is interpreted as an act by an actor who is obviously intentional or negligent and then there is another intervening act that has an impact or effect or damage that cannot be controlled by the previous offender (Boberg, 1959). The phrase novus actus interveniens in the American Restatement of the Law of Torts is translated with intervening force, which is defined as something, that actively generates hazard or damage to the other and then after that, there is an act or omission by another actor that has an impact. Because there are a novus actus interveniens, a question that frequently arises is whether the first actor is feeling responsible, because several new conditions are actively causing destruction or danger (Boberg, 1959).

In German family literature, Novus actus interveniens is known as Überholende kausalität which is defined as the second cause following the first cause. In this case, we are dealing with the issue of interruption of the first cause by the second one. There can be two possibilities for the emergence of a second cause; the first possibility is that it is foreseeable and the second is that the second cause is unforeseeable (J. Remmelink, 2014). Furthermore, Remmelink (2014) said that:

"If the second cause was indeed foreseeable, then that cause is basically placed in the causal chain so it can reduce or remove the liability of the first offender. In this case we cannot speak of Überholende kausalität. In this case the application of the reasoning test also becomes 
important as a correction. Thus, in negligent delicts, predictability will quickly be assumed, and even in intentional delicts it can be said that the result is foreseeable and may be the beginning of the emergence of a negligent delict for the first actor."

According to Remmelink (2014), if the second offense proved to be a stand-alone intentional delict, then the issue becomes more complicated. This is where the doctrine of novus actus interveniens is required. This teaching was introduced by Frank, a famous German law specialist. He cited a case once decided by the Bundesgerichtschof (BGH) in 1954. In this case, A poisons B, then B should have died within one hour, but before the hour passes, C shoots B and B were dead. The shooting by $\mathrm{C}$ is a stand-alone act. Thus, C's action is the cause of B's death and not the act of A. However, A can still be convicted of attempted murder.

Intervention can also be conducted by the victim. It means that the victim contributes to the emergence of a prohibited result. When the victim intervenes in the causal chain, the actions of the victim cannot be predicted by the perpetrator, giving rise to another result than the act committed by the offender. For example, a pickpocket takes the purse of a girl on a moving train, because the girl is startled she suddenly jumps out of the fast moving train which results in her death by crashing on the train platform. The pickpocket cannot account for the death of the girl, because of excessive actions were taken by the victim that therefore remove the responsibility of the pickpocket. An interesting example is also given by Hart and Honore (1959) in a hypothetical case in which there would be no result without the victim's actions. For example, A intends to kill B by putting poison into B's food. Moreover, B is, in fact, aware that there is poison in the food and aware that eating the food will have fatal consequences. B still eats the food, and this causes his death. In this case, B's death cannot be attributed to A's deed. Moral consideration is one of the justifications, B was aware of the poison in the food, and was eating the food without pressure and intentionally took the meal and ate it and died. However, if B was not aware of any poison in the food and ate it and then died, then his death can be attributed to A's deed. In this case, B has contributed to his death, B's deeds and errors are the cause of his death, removing A’s liability (J. Remmelink, 2014).

In some cases, intervention can also be conducted by medical personnel associated with medical measures for healing a patient who is a victim of crime. When a doctor or other medical workers such as nurses attempt to cure a patient, it turns out that the act of curing has worsened the condition of the victim that leads to death. Another possibility is that the patient suffers a hereditary disease when he becomes a victim of crime, and when the medics heal the wounds connected with the criminal offense, the hereditary disease causes his death. Some other issues appear when patients who are victims of crime refuse to get medical help, with the result that their condition worsens because of the wounds they suffer which can cause death.

In the case of murder, for example, the original injuries suffered by the victim of that crime did not directly cause the instantaneous death of the victim. The victim is then treated at the hospital, it turns out to be a medical error. This error caused the death of the victim and not the injuries he suffered from the act of the perpetrator. In this case, certainly the offender cannot be held responsibility for the death of the victim, therefore the perpetrator of the crime should not be charged with the criminal act of murder but with torture. Because if there was no error in the medical treatment, the victim may still be alive. The medics who performed the medical procedure have done an intervention that breaks the chain of causality (J. Remmelink, 2014).

The doctrine of novus actus interveniens is not so popular among Indonesian law specialists, even in jurisprudence this doctrine is not used. This doctrine is unpopular because it is derived from the common law tradition (Keiler \& Roef, 2015). In legal literature developed by Indonesian law specialists, this doctrine can be found in the teachings of causality, in determining the cause that causes the result. One theory used is the theory of individualizing the objective. In this theory, the cause is determined by a single factor that adds or contributes most to the result (Moeljatno, 2002). In 
determining the most influential or the most contributing factor, it turns out that the experts in criminal law have different opinions. Birkmeyer, for example, defines it regarding quantity that is produced, he illustrates this with a wagon that cannot be pulled by one horse and can only be pulled by two horses. And the two horses are the cause and not one of them. While Kohler has a different opinion, he argues that the factor causing the result is the factor that contributes most according to its nature. Therefore, it is not the accumulation of various causes such as argued by Birkmeyer (Moeljatno, 2002).

Birkmeyer's theory does not argue for the existence of novus actus interveniens because one factor cannot eliminate the other. While Kohler explains that, the doctrine of novus actus interveniens is accepted, because one factor can beat or intervene between other factors if that factor is by its nature more powerful than any other factor. So if exemplified by the two horses that pull the wagon, it is not the accumulation of the horses that causes the wagon to be pulled, but the power of the strongest horse (Moeljatno, 2002).

To determine the most influential factor, first of all, it should be based on the size of the act rather than the size of the error and the two should not be confused. For example, A abuses B, and then in the middle of the road when about to be taken to the doctor, B has an accident and dies. If his death is caused by the accident, then there is no causal relationship between A's act and B's death (Moeljatno, 2002). In this regard, it can be interpreted that the accident suffered by B breaks the chain of A's actions so that the causality is disconnected and A's responsibility for B's death is removed. Another example is that of a forgery, A wants to erase a word in a letter, but apparently the word did not disappear. Then B also wants to erase the word and uses another fluid to erase it. It turns out that the combination of these fluids makes the word disappear. The abolition of the word cannot be contributed to A's deed because A's act has been intervened by B's deed (Moeljatno, 2002).

The individualizing theory limits the event that is considered as the cause based on the facts after the offense has occurred (post factum). Which event among a series of events is more likely to cause the result? This theory is also known as the exclusive theory or individualiserende theorie. According to this theory, after an event has happened, not all factors among a series of factors associated with that event are causing factors. A causing factor is just the factor that plays the biggest part, or the dominant factor or the factor that has contributed the most to the result, while the other factors are assessed as conditional factors only and not as the causing factor. In this case, each of the factors is assessed and the strongest factor is chosen as the cause that can be accounted for. Thus, the other factors are eliminated and not used as the factor that leads to the result. However, it is not easy to determine the most influential factor and the factors that have no effect, because it is not easy to determine the strength of the influencing factors, so there is still an obstacle in determining the strength of these factors. Hence, we need a special formula in determining the strength of the factors that lead to the prohibited result, and the supporters of the individualizing theory still have not found that formula.

Thus, there is a significant difference in determining the causing factor. In the individualizing doctrine, the most influential factor is measured, so that the factors that are not influential are eliminated. While in the novus actus interveniens doctrine, the contrary is done namely measuring the intervening factors. Factors that intervene are considered as factors that break the chain of the most influential factor. While, according to Boberg (1959), this most influential factor in some cases can be equated with the novus actus interveniens.

In a judgment, the court illustrates how the doctrine of novus actus interveniens is used even though the court did not literally mention this terminology. The case stems from an employee at a car showroom who received an advance payment for the purchase of a car from a customer. However, this payment was never deposited into the official bank account of the company but was put into the employee's bank account. It turned out that it was not the first time but already the second time the employee did this. The manager of the car showroom is aware of the employee's act, because of a 
complaint made by the customer that the car he ordered has exceeded the time limit agreed to be processed. Therefore, the showroom manager asks the employee to immediately return and deposit the money into the company's showroom bank account. The employee still does not return the money after the specified period, but only gives the certificate of ownership of his motorized vehicle as a deposit with a value still far below the value of the money he received from the customer. Fearing that the employee would flee, the manager of the showroom then prohibits the employee from going home and locks him in the living room of the showroom monitored by security. On the next day, the employee has hanged himself, and based on the results of the post-mortem examination; circular abrasions are found in his neck and based on the results of the medical examination this is a sign of suffocation. In this case, the prosecutor charged the showroom manager with alternative charges. He was charged with violation of personal freedom that led to death, as stipulated in Article 333 paragraph (3) of the KUHP or violating someone's freedom stipulated in paragraph 333 (1) of the KUHP (Decision No.782/Pid. B/2013/PN.Jkt.Pst: 3-8).

About this claim, the judge found that the death of the victim was not caused by the act of the defendant but the result of the victim's actions. This means that there is no causal relationship between the violation of the victim's freedom and the death of the victim. The victim has hanged himself, which led to his death. In other words, the victim has intervened and broken the chain of causality. Because there is an intervention by the victim, the offender cannot be held accountable for the alleged criminal cause of death.

Another court decision that describes the intervention of the victim is the case of a female victim that occurred in Bandung. Two perpetrators, Wawan and Awing, see a woman opening the gate of a house, while the front door of the car stays open. Both of the perpetrators get off their motorbike and take a bag belonging to the victim from inside the car. The victim sees it and tries to take back her bag and before she chases them. She embraces the neck of the perpetrator on the back of the motorcycle that is still moving in high speed so that the victim is dragged along. To free himself from the embrace, the perpetrator nudges her with his elbow, but the victim still does not release him and eventually the perpetrator pulls a machete and slashes in the victim's direction as much as three times. Due to the stabbing the embrace of the victim weakens until she falls, but when she falls the victim's hair gets caught in the chains and she is dragged along a few meters ahead, the victim dies as a result. Based on the results of the post mortem examination the death of the victim is caused by heavy bleeding in the brain caused by a blunt object. In this case the prosecutor charged the perpetrator with violent theft resulting in death (Article 365 paragraph 4 of the KUHP) or murder accompanied by other criminal acts (article 339 of the KUHP) (Decision No. 124/Pid/2014/PT.Bdg: 3 -6).

In reaction to this charge the legal advisor of the defendant states that the defense act that committed by the defendant has to be considered as a ground for justification and forgiveness, because the victim acted alone and endangered herself. If the victim had not acted excessively then the victim would not have experienced death. The court concluded that the defendant had caused the death of the victim and that there was no reason whatsoever that could justify the actions of the defendants (Decision No. 124/Pid/2014/PT.Bdg: 3-6).

In this case, the lawyer has incorporated the doctrine of novus actus interveniens, in the form of ground for justification and forgiveness. Regardless of whether the placement of the ground for justification and forgiveness is correct or not, it is accurate to compare the novus actus interveniens with a ground for justification and forgiveness. The lawyer has used logical thinking about the intervention of the victim that could break the chain of causality and could eliminate or reduce attribution of criminal responsibility of the perpetrator.

The following provides a court decision on a criminal offense of abuse causing death, but the victim's death was not caused by the perpetrator, but by the intervention of the victim. The act begins with the theft of the mosque's charity box. The theft of the charity box has happened several times 
before, and it is known that Faisal Akbar (FA) is the perpetrator. When FA is questioned at the police office other evidence that is found in the form of T's key. FA does not admit it, because of that an investigator named AL gets upset so that he kicks and beats FA. After receiving numerous acts of violence of the investigator, FA finally admits that he used T's key to steal a motorized vehicle. After the case had developed other perpetrators are arrested, namely Budri Zen (BZ), Al Indra (AI) and one of his men named Randi Agusta (RA). After the interrogation, because BZ does not admit his actions, both investigators hit BZ with sticks and then kick him. After being beaten and kicked repeatedly, the BZ finally confesses his deeds. The actions of the defendant resulted in the victim's weakened condition, his power decreased and he gets sick. After the two victims suffered abuse, the next day both are found dead in the bathroom, hanged by the neck with a T-shirt. The conclusion of the post mortem report is by examination of the victim's body, a circular wound in the neck is found, the bruises on his back, buttocks, and arms. External examination finds pressure and circular abrasions around his neck, on his limbs, buttocks, and bleeding on the left toe nails due to blunt force as well as signs of suffocation in several organs. For his actions, the attorney charged the defendant with Article 351, paragraph 3 of the KUHP, namely mistreatment resulting in death, or Article 351, or paragraph 2 of the KUHP or Article 351 paragraph 1 of the KUHP (Decision No. 135/Pid.B/2012/PN.MR: 5-12).

In one of the considerations, the judges held that the death of the two victims was not caused by the actions of the two defendants, but because of the circular wound in the neck that caused suffocation. Here is an excerpt from the consideration of the decision:

"Considering that based on the conclusions of the results of the post mortem autopsy report No. 01 /OTP/PII /XII /2011 dated January 4, 2012, in name of Budri M. Zen conducted by Dr. Rika Susanti, Sp.F, Doctor at the M. Djamil Padang hospital, it was stated that the cause of death in this organ is the result of blunt violence in the neck that caused suffocation. The estimated time of death was between 24 hours to 48 hours before the examination or less than 6 hours after the last meal."

The court also asked an expert testimony to determine the cause of death, here is an excerpt:

"Considering that the act committed by the defendants was not performed in the region of the neck that would cause suffocation, and the acts committed by the defendants are according to expert Rika Susanti not performed in a region of the body that causes death......."

In this case, the court used an adequate objective theory, i.e. finding the cause of death based on science. The victim's death had nothing to do with the acts of the defendants. The victim's acts of hanging themselves are the most powerful cause that led to their death, in other words, there is no causal relationship between the act of torture done by the defendants and the victims deaths. The victims broke the chain of causality by hanging themselves.

\section{CONCLUSIONS}

Novus actus Interveniens is a doctrine that contributes in determining the act that can break the chain of attribution of criminal responsibility. As a doctrine novus actus interveniens is used and developed in common law countries, this doctrine is used in the consideration of court decisions. The disruption of attribution of criminal responsibility can be caused by intervention of other actors, victims, medical personnel, and by natural factors.

Doctrinally, novus actus interveniens is interpreted as a doctrine in which one cause can set aside or eliminate another cause, in the sense that the most powerful cause or the cause that has the most influence can be considered as the cause leading to the prohibited result. Meanwhile in the 
practice of court ruling in Indonesia, the doctrine of novus actus interveniens is not applied as this concept developed in common law. Court decisions are limited to considerations of arguments raised in the teachings of causality. The law model which was built in the doctrine of novus actus interveniens, is a law model with an approach of legal reasoning to ensure whether there is an intervention by a third party that can disrupt the attribution of the first offender's liability, although it cannot eliminate all attribution of responsibility.

\section{REFERENCES}

Boberg, P. Q. R. (1959). Reflections on the Novus Actus Interveniens. The South African Journal, 76 S African L. J. 280.

Gerner, B. A. (2004). Black's Law Dictionary, $8^{\text {th }}$ Edition. USA: Thomson Business.

Hart, H.L.A., \& Honore, A. M. (1959). Causation in the Law, $1^{\text {st }}$ Edition. Oxford: Oxford University Press.

Keiler, J., \& Roef, D. (2015). Comparative Concepts of Criminal Law. Cambridge: Intersentia.

Mahkamah Agung Republik Indonesia. 2010. Putusan Mahkamah Agung No. 862 K/Pid.Sus/2010. Tentang Pidana Khusus.

Mahkamah Agung Republik Indonesia. 2012. Putusan Mahkamah Agung Nomor: 135/Pid.B/2012/PN.MR. Tentang Pidana Khusus.

Mahkamah Agung Republik Indonesia. 2013. Putusan Mahkamah Agung No. 782/Pid.B/2013/PN.Jkt.Pst. Tentang Kejahatan terhadap Kemerdekaan Orang Lain.

Mahkamah Agung Republik Indonesia. 2014. Putusan Mahkamah Agung No. 124/Pid/2014/PT.Bdg. Tentang Pidana Pemalsuan Surat.

Moeljatno. (2002). Asas-Asas Hukum Pidana. Jakarta: Rineke Citpa.

Remmelink, J. (2014). Pengantar Hukum Pidana Material 1 (Inleiding Tot De Studie Van Het Nederlandse Strafrecht). Yogyakarta: Maharsa Publishing. 